BIBLIOTEKA 2018, NR 22 (31)

PL ISSN 1506-3615

DOI: $10.14746 / \mathrm{b} .2018 .22 .2$

\author{
JAKUB ŁUKASZEWSKI \\ Uniwersytet im. Adama Mickiewicza w Poznaniu, \\ Biblioteka Uniwersytecka
}

\title{
Rejestr ksiąg Stanisława Smoły z Wolborza w inkunabule ze zbiorów Biblioteki Uniwersyteckiej w Poznaniu
}

\begin{abstract}
Streszczenie. Biblioteka Uniwersytecka w Poznaniu w 2017 roku nabyła wydanie dzieła Wilhelma Duranta Rationale divinorum officiorum (Nürnberg: Antonius Koberger, 19 IV 1480, 2). Na wyklejce przedniej okładki tego inkunabułu znajduje się spis ksiąg z 1553 roku. W artykule przedstawiono losy tego woluminu (dotąd uchodził za stratę wojenną) oraz dokonano analizy spisu ksiąg. Wynika z niej, że właścicielem księgozbioru ujętego w rejestrze był Stanisław Smoła z Wolborza (pierwsza połowa XVI wieku), bakałarz sztuk i rektor szkoły przy kościele św. Szczepana w Krakowie. Do tekstu artykułu dołączono edycję treści spisu ksiąg z objaśnieniami.
\end{abstract}

Słowa kluczowe: rejestr (spis) ksiąg, edycja, inkunabuł, stare druki, Stanisław Smoła (Szmola) z Wolborza, Paweł z Piotrkowa, księgozbiory krakowskie XVI wieku.

W 2017 roku Pracownia Starych Druków Biblioteka Uniwersyteckiej w Poznaniu zakupiła 59 druków w 34 woluminach. Są to nabytki z aukcji organizowanych przez antykwariaty w Warszawie, Krakowie i Bydgoszczy oraz zakupy od osób prywatnych. Biblioteka wzbogaciła się przede wszystkim o inkunabułowe wydanie dzieła Wilhelma Duranta Rationale divinorum officiorum z norymberskiej oficyny Antona Kobergera, wydrukowane 19 kwietnia 1480 roku$^{1}$. Było to bardzo popularne w średniowieczu dzieło, do końca XV wieku ukazało się drukiem ponad 40 razy. Zakupiony egzemplarz to pierwsze norymberskie wydanie, ale jest licznie reprezentowane w polskich i zagranicznych bibliotekach. Skąd więc decyzja o jego kupnie? Dokładny opis tego zabytku zamieszczony

1 Incunabula quae in bibliothecis Poloniae asservantur, t. 1, moderante A. Kawecka-Gryczowa composuerunt M. Bohonos, E. Szandorowska, Wratislaviae 1970, nr 2019 (dalej: IBP); Gesamtkatalog der Wiegendrucke, t. 1-7, Leipzig 1925-1940, t. 8-12, Stuttgart 1978-2013, nr 9121 (dalej: GW). 
w katalogach aukcyjnych antykwariatu „Rara Avis” w Krakowie wskazywał, że jest to stosunkowo dobrze zachowany, zdobiony oraz opatrzony marginaliami z XV/XVI wieku egzemplarz ${ }^{2}$. W szczególności jednak zwracał uwagę rękopiśmiennym spisem ksiąg bliżej nieznanego Pawła z Piotrkowa z 1553 roku, umieszczonym na papierowej wyklejce przedniej okładki (w katalogach aukcyjnych spis datowano błędnie na przełom XV i XVI wieku). W poniższym tekście omówię losy tego inkunabułu oraz przedstawię krytyczną edycję wspomnianego rejestru ksiąg, które pierwotnie nie należały jednak do Pawła z Piotrkowa, ale, jak postaram się wykazać, do Stanisława z Wolborza zwanego Smoła ${ }^{3}$.

Wolumin od razu wzbudził zainteresowanie bibliotekarzy i badaczy dawnej książki. Pomimo tego nie znalazł on nabywcy na aukcjach organizowanych przez antykwariat „Rara Avis” w 2016 i 2017 roku. Co więcej, pracownik Biblioteki Narodowej, inkunabulista Michał Spandowski, zwrócił uwagę, iż może to być egzemplarz dotąd uchodzący za stratę wojenną ${ }^{4}$, a pierwotnie pochodzący z biblioteki klasztoru augustianów eremitów w Krakowie ${ }^{5}$. Spandowski próbował zainteresować zakupem tej księgi Uniwersytet Jagielloński (Biblioteka Jagiellońska w 1950 roku przejęła historyczny księgozbiór po krakowskich augustianach ${ }^{6}$ ) oraz

2 Antykwariat "Rara Avis" 116 aukcja antykwaryczna książki - rękopisy - plakaty, Kraków 20 lutego 2016, Kraków 2016, nr 555, s. 138-139 (wyceniony na 12 tys. zł); Antykwariat "Rara Avis" 121 aukcja antykwaryczna ksiażki - plakaty, Kraków 21 października 2017, Kraków 2017, nr 669, s. 147 (wyceniony na 19,8 tys. zł).

3 Opis bibliograficzny zakupionego inkunabułu oraz edycja treści rejestru z objaśnieniami zostały dołączone niżej w aneksie.

4 Inkunabuty zarejestrowane w centralnym katalogu do września 1939, po roku 1945 nie odnalezione na terenie Polski, w: Incunabula quae in bibliothecis Poloniae asservantur, t. 2: Addenda. Indices, moderante A. Kawecka-Gryczowa composuerunt M. Bohonos, M. Spandowski, E. Szandorowska, Wratislaviae 1993, nr +884 (dalej: +IBP).

5 W Bibliotece Narodowej częściowo zachowały się przedwojenne zeszyty, w których pod kierownictwem Kazimierza Piekarskiego prowadzono rejestrację inkunabułów z terenów Rzeczypospolitej. Wśród nich jest i zeszyt dotyczący biblioteki krakowskich augustianów, por. M. Spandowski, Polskie zbiory inkunabułów zniszczone, rozproszone i przemieszczone w czasie $i$ w wyniku II wojny światowej, "Rocznik Biblioteki Narodowej” 2013, t. 44, s. 7, przyp. 2. Spandowski przeanalizował ów zeszyt rejestracyjny i zwrócił uwagę, iż wolumin jest identyczny z opisanym przez Piekarskiego woluminem nr 133, ponadto udostępnił nam fotografie opisu Piekarskiego, za co mu w tym miejscu serdecznie dziękuję. Dodać trzeba jeszcze, że już w 1925 roku najpewniej ten egzemplarz wydania Rationale został ujęty przez Piekarskiego w Inwentarzu inkunabutów Bibljotek Polskich. Serja Pierwsza, Kraków 1925, s. 19, nr $62\left({ }^{*} \mathrm{H}\right.$ 6483).

6 M. Spandowski, op.cit., s. 25; ponadto o bibliotece augustianów krakowskich: W. Zega, Rękopisy średniowieczne z klasztoru augustianów eremitów na krakowskim Kazimierzu, w: Mendykanci w średniowiecznym Krakowie, red. K. Ożóg, T. Gałuszka, A. Zajchowska, Kraków 2008, s. 163-167. 
Bibliotekę Narodową - niestety bez skutku. Zachodziła obawa, że inkunabuł ten wcześniej czy później trafi (znów? ${ }^{7}$ ) w prywatne ręce. W związku z tym Spandowski zasugerował, by księgę nabyła Biblioteka Uniwersytecka w Poznaniu. Bez zbędnych dyskusji podjęto tu decyzję o jej zakupie.

Na górnym i dolnym obcięciu bloku tego woluminu znajduje się monogram SN z zaćwieczonym krzyżykiem (il. 1). Literatura przypisuje go Stanisławowi zwanemu Szmola (Smoła), synowi Mikołaja z Wolborza ${ }^{8}$. Nie posiadamy o nim zbyt wielu informacji. Najpewniej mieszczańskiego pochodzenia, może być identyczny ze Stanisławem, który 3 marca 1509 roku został wyświęcony w Wolborzu na akolitę 9 . W semestrze letnim 1518 roku zapisał się na Uniwersytet Krakowski ${ }^{10}$, gdzie uzyskał stopień bakałarza sztuk w 1520 lub 1521 roku $^{11}$. W 1528 roku najpewniej jego wzmiankowano jako rektora szkoły przy kościele św. Szczepana w Krakowie ${ }^{12}$. Zmarł zapewne w roku 1553 lub krótko przed tą datą (wtedy jego księgi przeszły na własność Pawła z Piotrkowa, o czym niżej). Można przypuszczać, że Stanisław posiadał spory księgozbiór, z którego w polskich bibliotekach zachowały się co najmniej dwa rękopisy ${ }^{13}$, pięć inkunabułów ${ }^{14}$

${ }^{7}$ M. Spandowski, op.cit., s. 25, przyp. 111 - autor odnotował bez szczegółów, że w latach 90. XX wieku pojawiło się na rynku antykwarycznym identyczne wydanie Rationale (IBP 2019) z biblioteki augustianów krakowskich, ale trafiło w ręce prywatne. Czyżby to był opisywany tu egzemplarz?

${ }^{8}$ Taką identyfikacje monogramu znajdziemy w materiałach rejestracyjnych Piekarskiego oraz w pracy Inkunabuły Biblioteki Jagiellońskiej, oprac. A. Lewicka-Kamińska przy współudziale H. Friedberg, M. Kowalczyk, L. Tabeau, Kraków 1962, s. 263; A. Lewicka-Kamińska przy współudziale H. Friedberg, Inkunabuły Biblioteki Jagiellońskiej. Katalog przybytków za lata 1962-1967, „Biuletyn Biblioteki Jagiellońskiej” 1966, nr 2, s. 21 (Inc. 3352, poz. 20).

${ }^{9}$ W. Kujawski, Wykaz święconych z najstarszej księgi akt działalności biskupów włocławskich (Kurozwęckiego i Przerębskiego - lata 1496-1511), „Archiwa Biblioteki i Muzea Kościelne" 1999, t. 72, s. 90: „Stanislaus Nicolai de Wolborz Gnezn. d[ioec.]”.

${ }^{10}$ Metryka czyli album Uniwersytetu Krakowskiego z lat 1509-1551, wyd. A. Gąsiorowski, T. Jurek, I. Skierska przy współpracy R. Grzesika, Warszawa 2010, 1518e/111.

${ }^{11}$ Najstarsza ksiega promocji Wydziału Sztuk Uniwersytetu Krakowskiego z lat 1404-1541, wyd. A. Gąsiorowski, T. Jurek, I. Skierska, Warszawa 2011, 1520/29B lub 1521/21B. 111.

12 J. Krukowski, Nauczyciele szkót parafialnych Krakowa w XVI wieku, Kraków 2007, s. 17,

${ }^{13}$ Biblioteka Jagiellońska (dalej: BJ), rkps. 5302 (na obcięciu monogram Stanisława, opis rękopisu: Inwentarz rękopisów Biblioteki Jagiellońskiej: nr 4175-6000, oprac. W. Wisłocki, Kraków 1938, s. 382-384); rkps. Przyb. 160/54 (na obcięciu monogram Stanisława i jego wpisy proweniencyjne, por. też W. Zega, op.cit., s. 166, przyp. 16; zawartość rękopisu opisana w Rejestrze przybytków rękopiśmiennych BJ: www.bj.uj.edu.pl/akcesja/opisy).

${ }^{14}$ Są to inkunabuły Biblioteki Jagiellońskiej o sygnaturach Inc. 3207 i 3208 (Inkunabuty Biblioteki Jagiellońskiej, poz. 1034, 136), Inc. 3352 (A. Lewicka-Kamińska przy współudziale H. Friedberg, op.cit., poz. 20, pierwotnie współoprawny z drukiem o sygn. Teol. 2374), 
i pięć dzieł wydanych w XVI wieku ${ }^{15}$. Woluminy w charakterystyczny sposób opatrywał skrótami tytułów dzieł i swym monogramem, które to umieszczał na obcięciach bloku. Na przełomie XVI i XVII wieku większość księgozbioru Stanisława przejął Szymon, zakrystian katedry krakowskiej, który darował go bibliotece augustianów (świadczą o tym kolejne wpisy własnościowe w księgach). Stamtąd zbiór trafił do zasobów Biblioteki Jagiellońskiej.

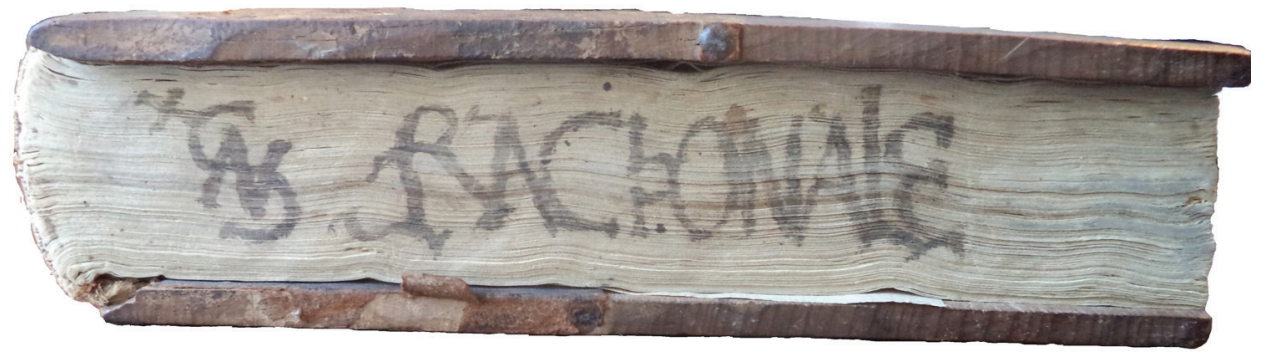

Il. 1. Inc. 394, dolne obcięcie - znak własnościowy Stanisława Smoły z Wolborza Źródło: Biblioteka Uniwersytecka w Poznaniu.

W zakupionym przez poznańską Bibliotekę Uniwersytecką inkunabule, pomijając jego niezwykle interesującą historię, najciekawszym elementem jest wykaz ksiąg zatytułowany: Regestrum librorum Pauli a Piortkow [!] et percipue que in isto scrinio sunt Anno Domini 1553 die Augusti prima, spisany na wyklejce przedniej okładki Rationale. O wspomnianym Pawle z Piotrkowa nie mamy żadnych wiadomości, poza źródłem, którym jest wykaz książek. Dowiadujemy się, że Paweł spisał księgi zdeponowane w skrzyni ${ }^{16}$, a każda z nich była opatrzona monogramem SN z krzyży-

Inc. 3100 (Inkunabuły Biblioteki Jagiellońskiej, poz. 803; por. niżej - Aneks ad 48). Jeden inkunabuł znajduje się w Bibliotece PAN i PAU w Krakowie (sygn. Inc. 149): Katalog inkunabutów Biblioteki Naukowej PAU i PAN w Krakowie, oprac. T. Dąbrowa, E. Knapek, J. Wojtowicz, Kraków 2015, s. 147, nr 97 (monogram Stanisława na obcięciu bloku błędnie odczytano jako "AS" i przypisano, choć ze znakiem zapytania, Andrzejowi Strzemboszowi).

${ }^{15}$ BJ Inc. 3205 (Katalog druków XVI wieku ze zbiorów Biblioteki Jagiellońskiej w Krakowie. BJ16, red. M. Malicki, t. 1-7, Baden-Baden 2002-2005 (dalej: BJ16), nr H-755), BJ Inc. 3206 (BJ16 W-26), BJ Teol 2374 (BJ16 I-72, pierwotnie współoprawny z Inc. 3352), BJ Inc. 3099 (BJ16 P-308, por. niżej - Aneks ad 47), BJ Inc. 3098 (BJ16 T-290, por. niżej - Aneks ad 46) (za pomoc w kwerendzie w zbiorach Biblioteki Jagiellońskiej serdecznie dziękuję Pani dr hab. Joannie Pypłacz). Jeden stary druk znajduje się w Bibliotece Uniwersyteckiej w Warszawie, por. Katalog druków XVI wieku w zbiorach Biblioteki Uniwersyteckiej w Warszawie, t. 6, P-Ska, red. H. Mieczkowska, Warszawa 2016, s. 426 nr 8352 (dalej: BUW16) (por. niżej - Aneks ad 23).

${ }^{16}$ Paweł wyraźnie pisze o księgach „que in isto scrinio sunt [wyróż. J.Ł.]”, sugerując, jak się wydaje, że skrzyń było więcej. 
kiem: In primis Rationale divinorum in marine superius signum talem est in omnibus vide $S N$ [wyróż. J.Ł.]. Księgę z wykazem umieścił zapewne jako pierwszą (może na wierzchu) w zbiorku woluminów, jako rodzaj przewodnika po zawartości skrzyni. Monogram (signum) SN należał do Stanisława z Wolborza, stąd wniosek, że i reszta książek z rejestru także pierwotnie należała do wolborczyka. Niestety, bez szczegółowej kwerendy, zwłaszcza w źródłach z archiwów krakowskich, nie da się odpowiedzieć na pytanie, w jaki sposób Paweł z Piotrkowa wszedł w posiadanie skrzyni pełnej książek Stanisława.

Rejestr ksiąg spisany został przez Pawła niestarannie i bardzo niejasno. Obejmuje co najmniej 52 dzieła w 28 woluminach. Tylko jedna księga, co wyraźnie zostało zaznaczone, była pergaminowym rękopisem (zob. Aneks, ad 8), pozostałe to z pewnością dzieła wydane drukiem. Co prawda większość autorów i dzieł można zidentyfikować, ale w rejestrze nie ma informacji o adresie wydawniczym czy szczegółach pozwalających określić konkretne edycje (co zresztą nie odbiega od ówczesnej praktyki). Piotrkowczyk pokusił się jedynie na, jak to byśmy dziś określili, podanie formatu bibliotecznego, charakteryzując rozmiar oprawy: in minori fractora ( $8^{\circ}$ ?), in mediocri $\left(4^{\circ}\right.$ ?), in maiori $\left(2^{\circ}\right.$ ?). Wygląda na to, że Paweł ułożył rejestr, sugerując się skrótami tytułów dzieł, zapisanych na obcięciach bloków, być może w niektórych przypadkach parafrazował niedokładnie informacje z kart tytułowych. Metodę jego pracy przy rejestrowaniu ksiąg najlepiej prezentuje opis zachowanego do dziś egzemplarza, w spisie pod numerem 4. Paweł opisał księgę w następujący sposób: Jop, David, Sapientie. Cóż za pozycja kryła się pod tym opisem? Okazuje się, że to klocek współoprawnych wydań dzieł Tomasza z Akwinu oraz Pelbarta z Themeswaru. Na obcięciach tego klocka Stanisław opisał skrótowo jego zawartość: Job Dauid Sapięntia (il. 2; obiekt jest przechowywany obecnie w Bibliotece Jagiellońskiej, sygn. Inc. 3098-3100, por. niżej - Aneks, ad 46-48).

Analiza całości spisu ksiąg ze skrzyni wskazuje, że, z drobnymi wyjątkami, zdeponowano w niej zwarty treściowo zbiór dzieł i traktatów o treści teologicznej. Zdecydowanie dominowało w nim kaznodziejstwo, $\mathrm{w}$ tym popularne $\mathrm{i}$ aktualne $\mathrm{w}$ pierwszej połowie XVI wieku zbiory kazań i homilii Friedricha Nauseae i Johanna Fabri oraz, najprawdopodobniej paryskie, wydania kazań autorów franciszkańskich: Jeana Tisseranda (kazania adwentowe) czy Bonifacio de Ceva (zbiór kazań wielkopostnych). Na liście pojawiły się bieżące traktaty antyprotestanckie (Phimostomus Johanna Dietenbergera i najpewniej De Sanctorum invocatione Johanna Cochlaeusa). Kolejną grupą były teksty biblijne, komentarze do nich oraz konkordancje. Są to więc niezidentyfikowane wydania tekstów Ewangelii 


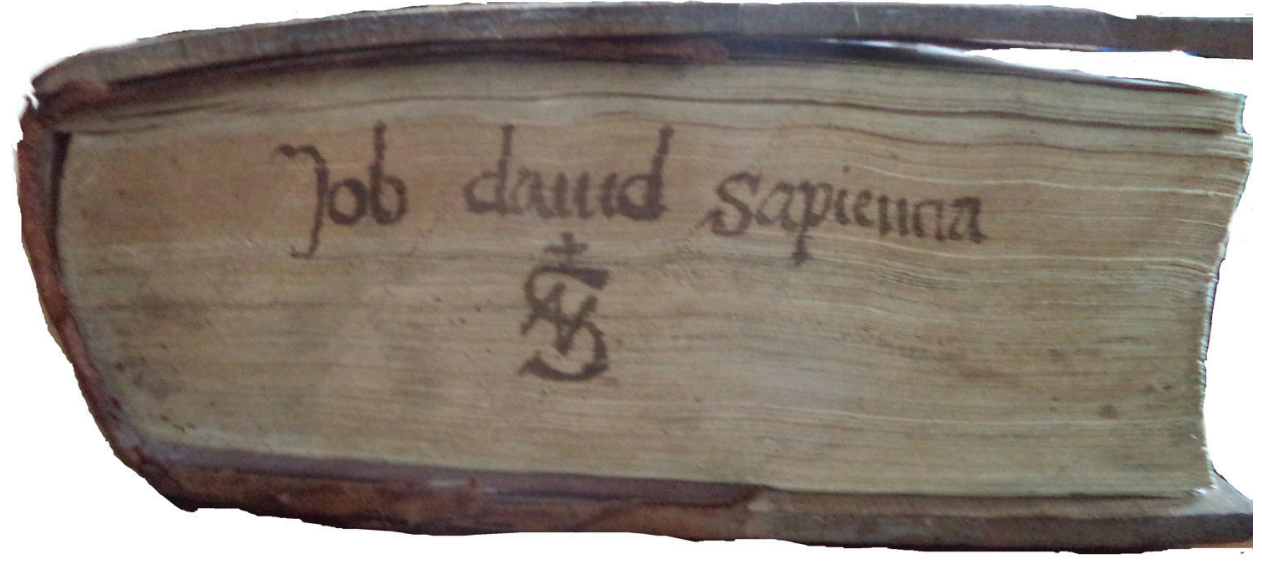

Il. 2. Inc. 3098-3100, dolne obcięcie Źródło: Biblioteka Jagiellońska.

(pasje Chrystusa i Liber generationis Jesu Christi wg św. Mateusza), komentarzy do ksiąg Starego i Nowego Testamentu (np. Alkuina In Genesim, św. Ambrożego do Listów św. Pawła, św. Augustyna De consensu Evangelistarum), Expositio in Psalterium Ludolfa z Saksonii czy Concordantiae minores. Nie zabrakło w spisie dzieł z dziedziny teologii moralnej, podręczników i traktatów spowiedniczych (autorstwa Dionizego Kartuza, Aleksandra de Ariostis, Richarda Rollego). Z wykładni liturgicznych wymienić trzeba oczywiście Rationale divinorum officiorum Wilhelma Duranta i Ruperta z Deutz De Divinis Officiis Libri XII. Teologię dogmatyczną reprezentował rękopiśmienny przekaz Summy teologicznej (zapisanej jako: Compendium Theologiae) Tomasza z Akwinu oraz Sententiarum Textus Piotra Lombarda. Z całości wyłamują się nierozpoznany opis Ziemi Świętej i dziełko italskiego humanisty Antonia Mancinellego, zasygnalizowane w rejestrze tylko nazwiskiem autora.

Warto teraz zadać pytanie o to, ile ksiąg zarejestrowanych w 1553 roku dotrwało do naszych czasów, pomijając oczywiście Rationale Duranta. Otóż zachowały się jeszcze co najmniej cztery woluminy zawierające sześć dzieł ${ }^{17}$.

Czy na podstawie rejestru ksiąg można spróbować powiedzieć coś więcej o ich pierwotnym użytkowniku - Stanisławie z Wolborza? Częściowo - oprócz tego, że był rektorem krakowskiej szkoły przy kościele św. Szczepana (co wiadomo skądinąd), wygląda na to, że był on chyba także czynnym kapłanem i kaznodzieją o zacięciu polemicznym, na bieżąco zaopatrującym się w księgarskie nowości z dziedziny sermonistyki

\footnotetext{
${ }^{17}$ Por. niżej - Aneks ad 5, 23, 46-48, 52.
} 
(co ciekawe, nie tylko z oficyn niemieckich, ale też z francuskich - paryskich i lyońskich). $\mathrm{W}$ analizowanym spisie brakuje popularnych $\mathrm{w}$ tym czasie utworów choćby Erazma z Rotterdamu, nie ma wydań klasyków łacińskich, nie ma również żadnych wydań niezbędnych przy obowiązkach rektora szkoły parafialnej, np. gramatyk łacińskich („Donatów”, Alexandra de Villa Dei czy choćby aktualnego Jakoba Heinrichmanna z Sindelfingen). Co niekoniecznie świadczy o tym, że wolborczyk takowych nie posiadał. Może po prostu in isto scrinio znalazły się tylko dzieła teologiczne, a - jak można sądzić - $\mathrm{w}$ innych skrzyniach, w równie uporządkowany sposób, Stanisław przechowywał inne księgi, a świadczą o tym inne woluminy $\mathrm{z}$ jego proweniencja, zachowane $\mathrm{w}$ krakowskich zbiorach $^{18}$. Stąd także trudno o całościowe oszacowanie ilościowe jego księgozbioru. Spis i inne znane egzemplarze krakowskie dają łącznie ok. 59 dzieł w 33 woluminach. W świetle opublikowanych, czy znanych, inwentarzy krakowskich mieszczan, studentów, a nawet części profesury Akademii Krakowskiej pierwszej połowy XVI wieku księgozbiór wolborczyka to przykład średniej kolekcji - liczącej kilkadziesiąt woluminów ${ }^{19}$.

Zakupiony przez Bibliotekę Uniwersytecką w Poznaniu inkunabuł to nie tylko dobrze zachowany, zdobiony egzemplarz. Jest to jedna z niewielu ksiąg, które udało się odzyskać, mimo że uchodziły za zaginione w czasie ostatniej wojny. Jej dodatkową wielką wartością jest spis ksiąg z przedniej wyklejki - cenne źródło do poznania dziejów czytelnictwa w Krakowie w pierwszej połowie XVI wieku, i to nie wśród elit intelektualnych - profesorów akademickich czy uczonych kanoników, ale wśród przedstawicieli niższego kleru, do których należał Stanisław z Wolborza.

${ }^{18}$ Są to jednak także wydania dzieł teologicznych, por. wyżej - przyp. 13-15.

${ }^{19}$ Leszek Hajdukiewicz szacował „przeciętną bibliotekę profesorów krakowskich pierwszej połowy XVI w." na „80-100 woluminów” - por. L. Hajdukiewicz, Biblioteka Macieja z Miechowa, Wrocław 1960, s. 86. Marcin Łysy z Krakowa (-1507) posiadał 68 dzieł, por. W. Szelińska, Biblioteki profesorów Uniwersytetu Krakowskiego w XV i początkach XVI wieku, Wrocław 1966, s. 181 i n.; A. Łosowska, Marcin (Eysy) z Krakowa, kanonik przemyskiej kapituty katedralnej i jego biblioteka, „Rocznik Przemyski” 2010, t. 46, z. 3, s. 19-26; K. Maleczyńska, Z dziejów księgozbiorów mieszczańskich w Polsce 1506-1572, Wrocław 1991, s. 25 (o księgozbiorach patrycjuszowskich), podobnie księgozbiory lekarskie „najczęściej liczyły kilkadziesiąt dzieł (ibidem, s. 28). Por. również A. Benis, Materyały do historyi drukarstwa i księgarstwa w Polsce. II. Inwentarze bibliotek prywatnych (1546-1553), "Archiwum do dziejów literatury i oświaty w Polsce" 1892, t. 7, s. 202-240. 


\begin{abstract}
ANEKS
DURANTI Guillelmus.

Rationale divinorum officiorum, Nürnberg, Antonius Koberger, 19 IV 1480. $2^{\circ}$.

HC 6483*20. GW 9121. IBP 2019 (†IBP 884 Kraków Augustianie).

Defekt: brak k. 174 (clxxiiij).

Proweniencja:

1. Stanisław Smoła z Wolborza = na dolnym i górnym obcięciu bloku wpisany monogram $\mathrm{SN}$ z zaćwieczonym krzyżykiem na literze $\mathrm{S}$;

2. A R(everendo) D(omi)no Simone Sacristiano Cathedralis Eccle(siae) Arce$n$ (sis) huic Biblioth(ecae) d(a)t(us);

3. Augustianie eremici - Kraków, informacja Michała Spandowskiego wg materiałów Kazimierza Piekarskiego;

4. Biblioteka Uniwersytecka w Poznaniu, zakup - antykwariat „Rara Avis", Kraków, X 2017.

Oprawa: deska, półskórek - skóra brązowa, zdobienia ślepym wyciskiem - starte, resztki klamer. Brak grzbietu, górna okładzina odseparowana od bloku.

Na k. 1 dwubarwny (czerwono-niebieski) filigranowy inicjał wstępny Q[uecumque] (il. 3); dalej liczne mniejsze filigranowe inicjaliki, lombardy, rubrykacje; bardzo liczne glosy łacińskie rubrą (jednej ręki, XV/ XVI wiek). Na przedniej papierowej wyklejce: „Regestrum librorum Pauli a Piortkow [!] et precipue que in isto scrinio sunt Anno domini 1553 die Augusti prima”; skrót tytułu dzieła: „Racionale” wpisany na górnym obcięciu.

Sygnatura: Biblioteka Uniwersytecka w Poznaniu, Inc. 394.
\end{abstract}

\title{
Spis ksiąg Stanisława Smoły z Wolborza i Pawła z Piotrkowa
}

Tekst wydany na podstawie instrukcji Adama Wolffa ${ }^{21}$; kolejne numery porządkowe dodane przez autora kursywą w nawiasach kwadratowych - do nich odnoszą się objaśnienia poniżej wydanego tekstu (il. 4).

Regestrum librorum Pauli a Piortkow[!] et percipue que in isto scrinio sunt Anno Domini 1553 die Augusti prima. Inprimis [1] Rationale

${ }^{20}$ W.A. Copinger, Supplement to Hain's Repertorium Bibliographicum, cz. 1, London 1895, s. 199 , nr $6483^{*}$.

${ }^{21}$ A. Wolff, Projekt instrukcji wydawniczej dla pisanych źródeł historycznych do połowy XVI wieku, „Studia Źródłoznawcze” 1957, t. 1, s. 151-181. 


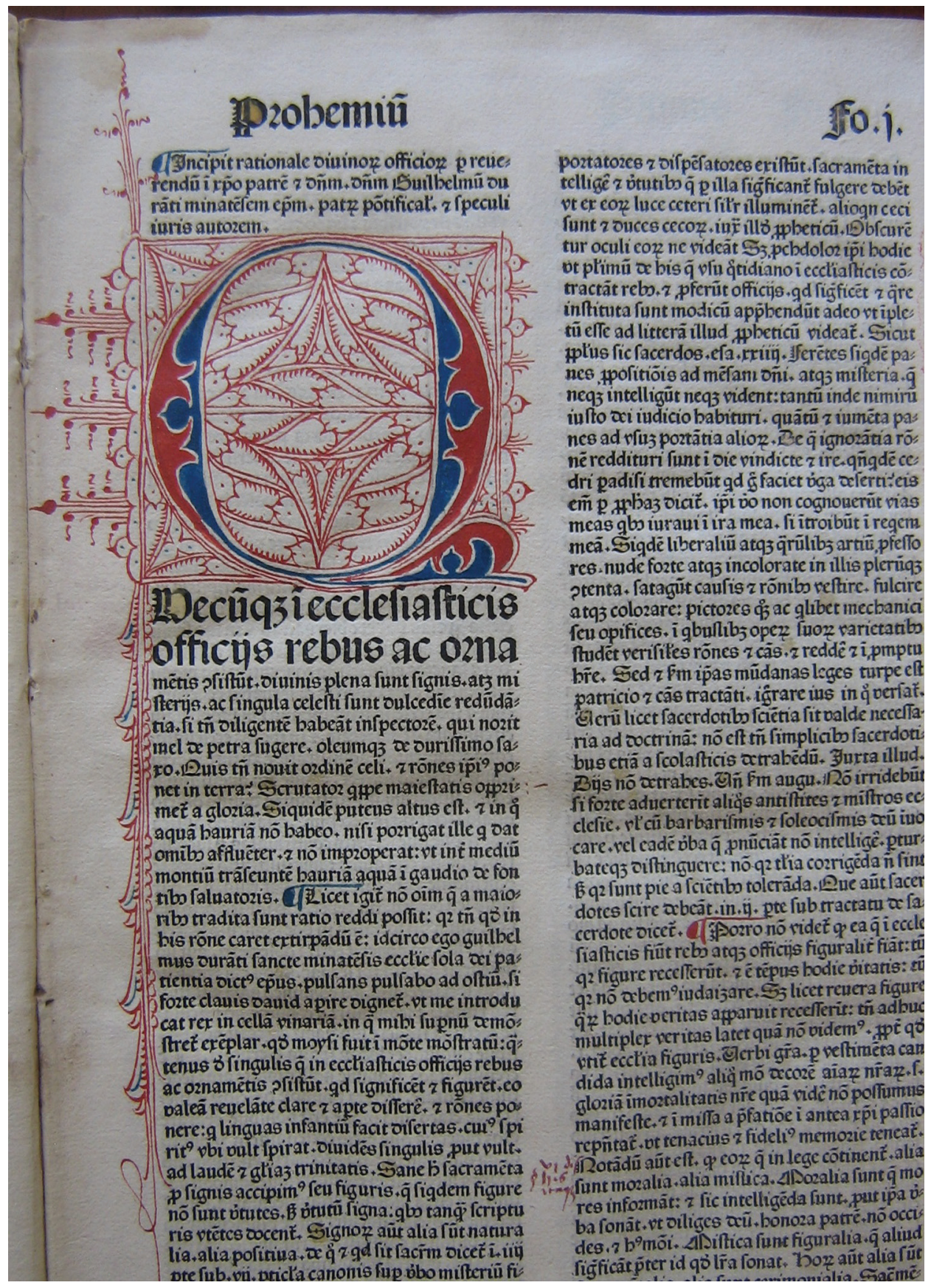

Il. 3. Inc. 394, inicjał wstępny Q[uecumque]

Źródło: Biblioteka Uniwersytecka w Poznaniu. 


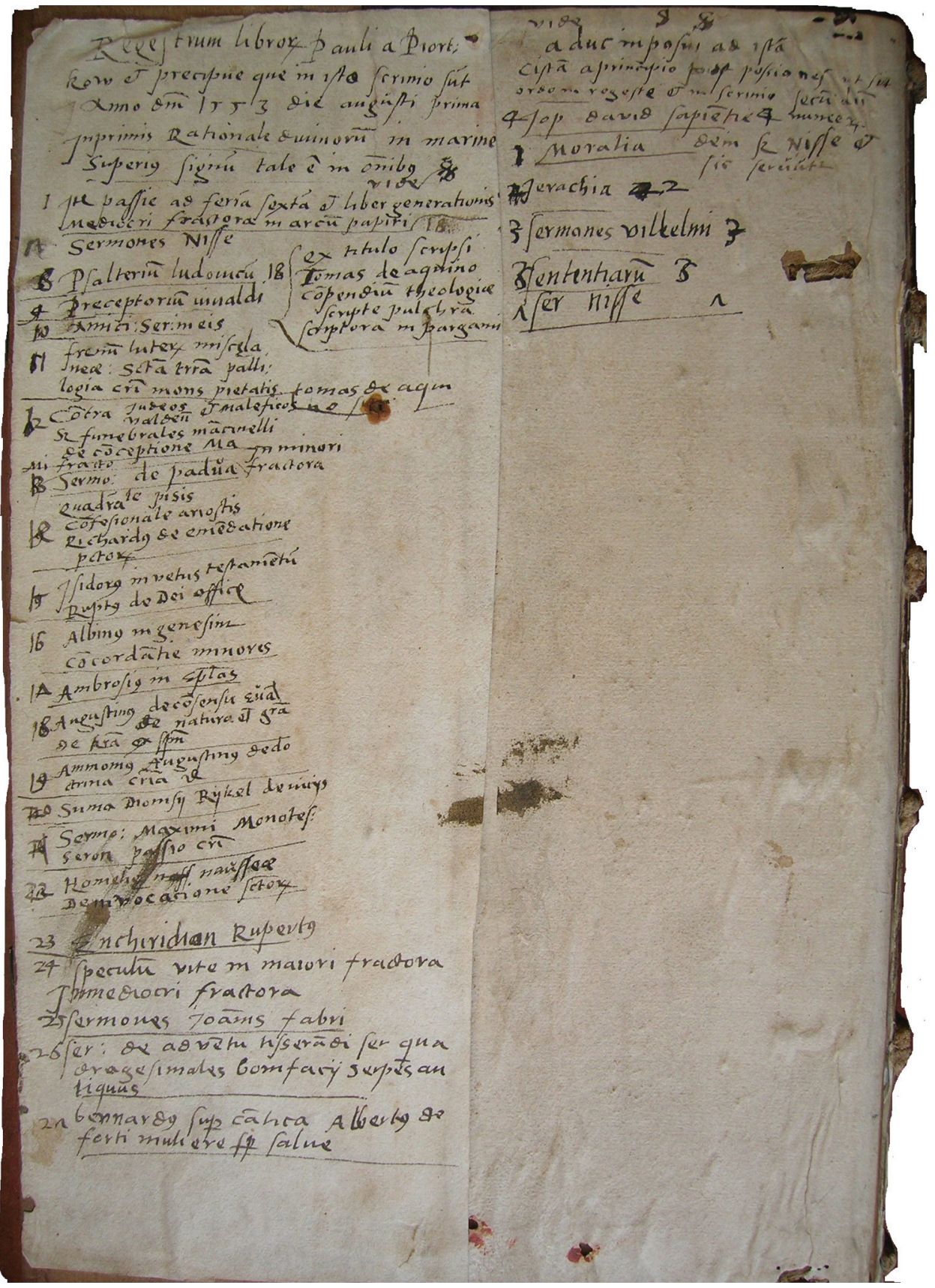

Il. 4. Inc. 394, rejestr ksiąg Stanisława Smoły z Wolborza (i Pawła z Piotrkowa) Źródło: Biblioteka Uniwersytecka w Poznaniu. 
divinorum in marine superius signum talem est in omnibus vide [ $t u$ wrysowany monogram wiazany SN z krzyżykiem zaćwieczonym na literze S].

1 Item [2] passie ad feriam sextam et [3] Liber Generationis in mediocri fractora in arcum papiri.

$7^{\mathrm{a}}$ [4] Sermones Nisse 22.

$8^{\mathrm{b}}$ [5] Psalterium Ludovicum.

$9^{c}$ [6] PreceptoriumVivaldi.

$10^{\mathrm{d}}$ [7] Amici Ser(mones) in eis $<18$ ex titulo scripsi [8] Tomas de Aquino compendium theologiae scripte pulchra scriptura in pargami[no] $>$.

11 [9] Frenu(m) Luter(anorum) [10] miscęl(lane)a S(an)cta T(e)rra, [11] Pallilogia Cristi, [12] Mons Pietatis, <[13] Tomas de Aquino sine>.

$12^{\mathrm{f}}$ [14] Co(n)tra Judeos et maleficos Walden(ses), [15] sermones funebrales, [16] Ma(n)cinelli, [17] de co(n)ceptione Marie.

In minori fractora:

138 [18] Sermo(nes) de Padva.

14 ${ }^{\text {h }}$ [19] Quadra(gesima)le Pisis, [20] Co(n)fessionale Ariostis, [21] Richardus de eme(n)datione $\mathrm{p}(\mathrm{ec})$ cator(um).

$15^{\mathrm{i}}$ [22] Isidorus in Vetus Testame(n)tu(m), [23] Rup(er)tus de Dei officiis.

16 [24] Albinus in Genesim, [25] Co(n)corda(n)tie minores.

17k [26] Ambrosius in Ep(isto)las.

$18^{1}$ [27] Augustinus de co(n)sensu Eva(ngelistarum), [28] de Natura et Gra(tia), [29] de L(itte)ra et Sp(irit)u.

19m [30] Ammonius, [31] Augustinus de Doctrina Cri(stian)a.

20n [32] Summa Dionisii Rykel de viciis.

$21^{\circ}$ [33] Sermo(nes) Maximii, [34] Monotesseron Passio Cristi.

$2^{\mathrm{p}}$ [35] Homelię Nauseae, [36] de invocatione S(an)ctor(um).

23 [37] Enchiridion, [38] Rupertus.

24 [39] Speculu(m) vite in maiori fractora.

In mediocri fractora

25 [40] Sermones Joannis Fabri.

26 [41] Sermones de Adventu Tissera(n)di, [42] Ser(mones) quadragesimales Bonifacii, [43] Serpens Antiquus.

27 [44] Bernardus super Cantica, [45] Albertus de forte muliere s(em) $\mathrm{p}(\mathrm{er})$ salve.

22 Oznaczenia literowe wskazują na wprowadzone poprawki: a początkowo $\mathrm{nr} 2$, poprawiono na $7 ;{ }^{\mathrm{b}} \mathrm{nr} 3$ poprawiono na $8 ;{ }^{\mathrm{c}} \mathrm{nr} 4$ poprawiono na $9 ;{ }^{\mathrm{d}} \mathrm{nr} 5$ poprawiono na 10 ; ${ }^{\mathrm{e}} \mathrm{nr} 6$ poprawiono na $11 ;{ }^{\mathrm{f}} \mathrm{nr} 7$ poprawiono na $12 ;{ }^{\mathrm{g}} \mathrm{nr} 8$ poprawiono na $13 ;{ }^{\mathrm{h}} \mathrm{nr} 9$ poprawiono na $14 ;{ }^{\mathrm{i}} \mathrm{nr} 10$ poprawiono na $15 ;{ }^{\mathrm{j}} \mathrm{nr} 11$ poprawiono na $16 ;{ }^{\mathrm{k}} \mathrm{nr} 12$ poprawiono na $17 ;{ }^{1} \mathrm{nr} 13$ poprawiono na $18 ;{ }^{\mathrm{m}} \mathrm{nr} 14$ poprawiono na $19 ;{ }^{\mathrm{n}} \mathrm{nr} 15$ poprawiono na 20; ${ }^{\circ} \mathrm{nr} 16$ poprawiono na 21; ${ }^{\mathrm{p}} \mathrm{nr} 17$ poprawiono na $22 ;{ }^{\mathrm{q}} \mathrm{nr} 2$ poprawiono na $4 ;{ }^{\mathrm{r}} \mathrm{nr} 1$ ? poprawiono na $3 ;{ }^{\mathrm{s}} \mathrm{nr} 4$ poprawiono na $2 ;{ }^{\mathrm{t}} \mathrm{nr} 3$ poprawiono na $5 ;{ }^{\mathrm{u}} \mathrm{nr} 3$ poprawiono na 6. 
Vide [tu dwukrotnie wrysowany monogram wiazany SN z krzyżykiem zaćwieczonym na literze S] Aduc inposui ad istam cistam a principio post Passiones ut sit ordo in regeste et in scrinio secundum numerum dein S(ermones) Nisse et sic secuntur.

49 [46] Jop, [47] David, [48] Sapientie 4.

$3^{\mathrm{r}}$ [49] Moralia.

$2^{\mathrm{s}}$ [50] Jerachia [!]2.

$5^{\mathrm{t}}$ [51] Sermones Wilhelmi 5.

$6^{\mathrm{u}}$ [52] Sententiarum 6.

7 Ser(mones) Nisse 7.

\section{Objaśnienia}

Identyfikacja pozycji $\mathrm{w}$ spisie dla ewentualnych edycji inkunabułowych na podstawie GW, dla druków XVI wieku na podstawie bazy USTC $^{23}$, bibliografii VD16 ${ }^{24}, \mathrm{FB}^{25}$, NB ${ }^{26}$ oraz katalogów BJ16, BUW16 i Herberta Mayowa Adamsa27.

ad 1. Duranti, Guillelmus (1237-1296), Rationale divinorum officiorum, Nürnberg: Antonius Koberger, 19 IV 1480. 2 (GW 9121). Obecnie Biblioteka Uniwersytecka w Poznaniu, sygn. Inc 394.

ad 2-3. Niezidentyfikowane wydania: Passio Jesu Christi oraz Liber Generationis Jesu Christi (wg Ewangelii św. Mateusza).

ad 4. Nicolaus de Nyse (?-1509), Sermones, wydanie niezidentyfikowane, do połowy XVI wieku znanych jest kilkanaście edycji (dane na podstawie USTC i VD16).

ad 5. Ludolphus de Saxonia (?-1377), In Psalterium expositio, Lyon: J. Moylin, 16 III 1518, 2. Adams L-1674. BJ16 L-696.

Prow.: 1. [Stanisław Smoła z Wolborza]: monogram SN z krzyżykiem na dolnym i górnym obcięciu; Stanislaus Szmola Wolborz Emptus 24 g. (wpis na przedniej wyklejce); Stanislaus Szmola Wolborz (wpis na k. tyt. i $\mathrm{dd}_{5} \mathrm{v}$ );

2. $I B$ - inicjały i gmerk wrysowane $\mathrm{w}$ pustej tarczy herbowej $\mathrm{w}$ ramce

${ }^{23}$ Universal Short Title Catalogue: https://www.ustc.ac.uk/index.php (dalej: USTC).

${ }^{24}$ Das Verzeichnis der im deutschen Sprachbereich erschienenen Drucke des 16. Jahrhunderts, t. 1-22, Stuttgart 1983-1995: https://www.vd16.de (dalej: VD16).

${ }^{25}$ French books III E IV: books published in France before 1601 in Latin and languages other than French, t. 1-2, red. A. Pettegree, M. Walsby, Leiden-Boston 2012 (dalej: FB).

${ }^{26}$ Netherlandish books. Books Publisched in the Low Countries and Dutch Books Printed Abroad before 1601, t. 1-2, red. A. Pettegree, M. Walsby, Leiden-Boston 2011 (dalej: NB).

${ }^{27}$ H.M. Adams, Catalogue of Books Printed on the Continent of Europe 1501-1600 in Cambridge Libraries, Cambridge 1967 (dalej: Adams). 
drzewortyniczej na k. tyt.; 3. Szymon zakrystian: A R(everendo) D(omi)no Simone Sacristiano arcensis d(onatus). Uwaga: na obcięciu górnym napis: Psaltęriu (m) Ludolphi.

Obecnie: Biblioteka Jagiellońska, sygn. Aug. 10016.

ad 6. Prawdopodobnie: Vivaldus Ioannesa Ludovicus, Vaere contritionis praecepta quae nihil prae se ferunt quam ipsam pietatem, znane wydania - Paris: A. Iurianus, 1546. $8^{\circ}$ (FB 90932 lub inne paryskie wydania z 1546 roku: FB 90933, 90934).

ad 7. Sermones Amici dicti, Basel: N. Kessler, 1495, 4 (GW 1616) lub Basel: N. Kessler, 1501. $4^{\circ}$ (VD16 S 6046).

ad 8. Thomas de Aquino s. (ca 1225-1274), najprawdopodobniej Summae theologicae - rękopiśmienny przekaz. W rejestrze opis jest niejasny, wynika z niego jednak, iż rękopis był pergaminowy i być może współoprawny z Sermones Amici (wyżej, ad 7).

ad 9. Dietenberger, Joannes (ca 1475-1537), Phimostomus scripturariorum [...] contra haereticos aeditus, Köln: P. Quentel, 1532, 4º (VD16 D 1501), w żywej paginie od k. sygn. M verso: Frenum Lutheranorum.

ad 10. Niezidentyfikowany opis Ziemi Świętej. Być może Burchardus de Monte Sion, Descriptio Terrae Sanctae (np. Antwerpen: J. Grapheus, J. Steelsius, 1536. 8, NB 5927) lub Haythonus, Liber historiarum partium Orientis, sive passagium terrae sanctae [...], Hagenau: J. Setzer, III 1529, $4^{\circ}$ (VD16 H 870).

ad 11. Prawdopodobnie Wimpina, Conradus (ca 1460-1531), Palillogia de theologico fastigio, ex nobilitate obiecti eius Christi, [Leipzig, M. Landsberg, ca 1501]. $4^{\circ}$ (VD $16 \mathrm{~K} \mathrm{1528).}$

ad 12. Bustis, Bernardinus de (ca 1450 - ca 1513), Defensorium Montis pietatis, cum additione Hieronymi Tornielli, [Milan: U. Scinzenzeler, post 31 I 1497]. $4^{\circ}$ (GW 5802) lub wydania XVI-wieczne, np. Hagenau, Augsburg: H. Gran, J. Rynmann, 7 IX 1503. 4 (VD16 B 1908); Hagenau, Augsburg: H. Gran, J. Rynmann, 7 IX 1513. 4 (VD16 B 1909); Hagenau, Augsburg: H. Gran, J. Rynmann, 20 VIII 1518. $2^{\circ}$ (VD16 1910).

ad 13. Thomas de Aquino s. (ca 1225-1274), dzieło niezidentyfikowane (może omyłkowo w tym miejscu zaczęto wpisywać nr 8?).

ad 14. Niezidentyfikowane traktaty Contra Judaeos i Contra Waldenses.

ad 15. Może: Ioannes de Sancto Geminiano (?-post 1346), Sermones funebres, wydanie niezidentyfikowane, w druku od 1499 (GW M14687).

ad 16. Mancinellus, Antonius (1452-post 1503), dzieło niezidentyfikowane.

ad 17. Niezidentyfikowany traktat lub kazanie De conceptione Mariae.

ad 18. Może: Antonius de Padva, s. (1195-1231), Quadragesimales sermones, wydanie: Paris, J. Bade, 1521. $8^{\circ}$ (FB 53534). 
ad 19. Bartholomaeus de Rinoncio (Pisanus; de Sancto Concordio, ca 1338-1401), Sermones lucidissimi [...] super evangeliis quadragesimalibus [...], może: Lyon, R. Morinus, 1519. $8^{\circ}$ (FB 56043).

ad 20. Ariostis, Alexander de (?-1484?), Libellus [...] qui et interrogatorium sive enchiridion confessorum inscribitur, Lyon: M. Bonhomme, 1540. $8^{\circ}$ (FB 53742).

ad 21. Richardus Rolle (1290/1300-1349), De emendatione peccatoris opusculum, Antwerpen: M. de Keyser, 1533. $8^{\circ}$ (NB 26772); Köln: M. Novesianus, [post 8 VIII] 1535. $8^{\circ}$ (VD16 R 2144).

ad 22. Isidorus Hispalensis, s. (ca 560-636), Enarrationes [...] in Genesim, Exodum, Leviticum [...], może edycja kolońska: P. Quentel, J. Soter, 1530. $8^{\circ}$ (VD16 I 367).

ad 23. Rupertus, abbas Tuitensis (ca 1070-1129), De Divinis Officiis Libri XII, Köln: P. Quentel, 1526. 80 (VD16 R 3782).

Obecnie Biblioteka Uniwersytecka w Warszawie, sygn. Sd. 608.5624 (opis egzemplarza: BUW16 $\mathrm{nr}$ 8352).

ad 24. Alcuinus, Flaccus (ca 730-804), In Genesim Quaestiones, a Menardo Molthero restitutae, najpewniej wydanie in $8^{\circ}$, np. Hagenau: J. Setzer, III 1529. $8^{\circ}$ (VD16 A 1692).

ad 25. Concordantiae minores bibliorum, może edycja: [Hagenau: H. Gran], 1490. $4^{\circ}$ (GW 7288).

ad 26. Ambrosius, s. (ca 340-397), Commentarii in omnes divi Pauli epistolas, wydania in 8, może: Köln: J. Gymnich, I 1530. $8^{\circ}$ (VD16 B 4998) lub Köln, J. Gymnich, III 1532. $8^{\circ}$ (VD16 ZV 1695), i inne edycje.

ad 27. Augustinus Aurelius s. (354-430), De consensu evangelistarum, Libri IV, najpewniej wydanie in $8^{\circ}$, może: Köln: J. Gymnich 1529. $8^{\circ}$ (VD16 A 4189 lub ZV 743); Köln: H. Fuchs, 1539. 8 (VD16 A 4190); Paris: C. Guillard, 1538. $8^{\circ}$ (FB 55163).

ad 28-29. Augustinus Aurelius s. (354-430), De Natura et Gratia; De Spiritu et Littera. Znane liczne edycje do połowy XVI wieku, tu najpewniej wydania tych dzieł in $8^{\circ}$, może jedna z edycji kolońskich, np.: De Natura [...], Köln: H. Fuchs, 1527. 8 (VD16 A 4223); De Spiritu [...], Köln: H. Fuchs, 1527. $8^{\circ}$ (VD16 A 4239). Znane są też edycje współwydane, np. Nürnberg: J. Petreius, 1524. $8^{\circ}$ (VD16 A 4222).

ad 30. Może: Ammonius Alexandrinus (III wiek n. e.) i jedno z jego dzieł: Evangelicae historiae ex quatuor Evangelistis, edycje łac.: Augsburg: S. Grimm, S. Ruff, XI 1523. 4 (VD16 B 4630); lub Quatuor Evangeliorum consonantia, np. wydania: Mainz: J. Schöffer, 1524. $8^{\circ}$ (VD16 B 4631); Köln: E. Cervicornus, 1532. $8^{\circ}$ (VD16 B 4634).

ad 31. Augustinus Aurelius s. (354-430), De Doctrina Christiana, liczne edycje drukowane (samoistne od ok. 1480 roku, GW 2902). 
ad 32. Dionysius Carthusianus (1402-1471), Summae Vitiorum et virtutum libri duo, może: Köln: J. Soter, 1533, 8 (VD16 D 1966).

ad 33. Przypuszczalnie: Maximus, episcopus Taurinensis, s. (ca 380 post 465), Opus insigne Homiliarum hyemalium $\mathcal{E}$ aestiualium [...], np. Köln: J. Gymnich, 1535. $8^{\circ}$ (VD16 M 1678).

ad 34. Znane są liczne wydania harmonii ewangelicznych tzw. Monotessaronu, od XV wieku zwłaszcza w opracowaniu Jana Gersona, tu najpewniej jednak edycja dzieła Gercharda Loricha, Monotessaron Passionis Christi Iesu, Solingen: J. Soter, 1538. $8^{\circ}$ (VD16 L 2514).

ad 35. Nausea, Friedrich (ca 1496-1552), Homiliae; wydanie niezidentyfikowane, do połowy XVI wieku ukazało się co najmniej 12 razy (dane z USTC i VD16).

ad 36. Jedno z polemicznych dzieł dotyczących wzywania świętych, najpewniej o antyprotestanckiej wymowie. Może: Cochlaeus, Johannes (1479-1552), De Sanctorum invocatione [...], Ingolstadt: A. Wießenhorn, 1544. 4º (VD16 C 4381).

ad 37. Enchiridion, popularna nazwa licznie wydawanych w XVI wieku „podręczników”, zawierających podstawowe informacje z danej dziedziny; dzieło, autor i wydanie niezidentyfikowane.

ad 38. Może: Rupertus, abbas Tuitiensis (ca 1070-1129), dzieło niezidentyfikowane.

ad 39. Rodericus Zamorensis (1404-1470), Speculum vitae humanae; liczne wydania znane od 1468 roku (GW M38498, IBP 4774); tu może wydanie: Straßburg: J. Prüß, 12 I 1507. $2^{\circ}$ (VD16 R 2700).

ad 40. Fabri, Johannes aus Leutkirch (1478-1541), Sermones, znanych jest kilka edycji różnych zbiorów kazań tego autora, w tym z wydań in 4\%: np.: Lepizig: M. Lotter, 1528 (VD16 F 205); Wien: J. Singrenius, IV 1528 (VD16 F 206) i inne; być może pod tą pozycją w spisie krył się klocek z kilkoma edycjami kazań J. Fabri.

ad 41. Tisserand, Jean (-1497), Sermones de Adventu, może Paris: P. Gromors, 1517. $4^{\circ}$ (FB 88926, oraz FB 88927-88928).

ad 42. Bonifacio de Ceva (ca 1456-1517), Opus admodum insigne sermones quadragesimales complectens, znanych jest co najmniej siedem wydań paryskich $\mathrm{z}$ lat 1517-1518, np. [Paris]: B. Rembolt. $8^{\circ}$ (FB 58644), kolejne, in $4^{\circ}$ : FB 58645, 58651-58655.

ad 43. Huet, Guillaume (-ca 1522), Serpens antiquus de septem peccatis criminalibus, [Paris]: J. Bade, 1518. $8^{\circ}$ (FB 74506) oraz inne wydanie paryskie z 1518 roku (FB 74504) i lyońskie z 1528 roku (FB 74507).

ad 44. Bernardus Claravallensis, s. (1090-1153), Sermones super Cantica Canticorum, edycja niezidentyfikowana, znane wydania od 1481 roku (GW 3934, IBP 917); w formacie in $4^{\circ}$ od 1494 roku (GW 3936). 
ad 45. Pseudo-Albertus Magnus (1193, ca 1206-1280), De muliere forti, Köln: H. Quentell, 7 V 1499. 4 (GW 699).

ad 46-48. Klocek zawierajacy 3 dzieła:

ad 46. Thomas de Aquino s. (ca 1225-1274), In librum beati Job expositio, Venezia: S. de Luere, A. Calcedonius, 3 III 1505, 2. Adams B-1345, BJ16 T-290.

Obecnie Biblioteka Jagiellońska sygn. Inc. 3098 (współopraw. z Inc. 3099-3100).

ad 47. Pelbartus de Themeswar (XV/XVI wiek), Expositio compendiosa et familiaris ... Sensus litteralem et mysticum complectens. Libri Psalmorum, Hagenau: J. Rynmann, H. Gran, 9 III 1513, 2. BJ16 P-308, VD16 P 1163. Obecnie Biblioteka Jagiellońska, sygn. Inc. 3099 (współopraw. z Inc. 3098-3100).

ad 48. Holkot, Robertus (?-1349), Super Sapientiam Salomonis, Reutlingen: I. Otmar, 1489, 2. GW 12887, IBP 2833.

Obecnie Biblioteka Jagiellońska, sygn. Inc. 3100 (współopraw. z Inc. 3098-3099).

Prow.: 1. [Stanisław Smoła z Wolborza]: monogram SN z krzyżykiem na dolnym i górnym obcięciu; Stanislaus Szmola Wolborz (wpis na przedniej wyklejce); Stanislaus Szmola a Wolborz (wpisy na kk. $\mathrm{A}_{2} \mathrm{v} 1$ i 2 pozycji w klocku, k. 139v 2 poz. w klocku, k. Q 6 v w 3 poz. w klocku); 2. Szymon zakrystian: A R(reverendo) D(omi)no Simone Sacristiano Cathedr(alis) Eccl(esiae) Arcen(sis) Huic Cracovien(sis) Biblioth(ecae) d(atus) (wpis na k. tyt. 1. pozycji w klocku); 3. Augustianie Kraków - pieczęć: Biblioteka KK. Augustianów w Krakowie. Przy kościele św. Katarzyny. Uwaga, na obcięciu górnym napis: Job Dauid Sapięntia b. Thomas, na dolnym: Job Dauid Sapięntia.

ad 49. Pozycja niezidentyfikowana, przypuszczalnie: Gregorius I Magnus, papa, s. (ca 540-604), Moralia in Job, edycja niezidentyfikowana; do połowy XVI wieku znane są liczne wydania.

ad 50. Pseudo-Dionysius Areopagita, Caelestis hierarchia, wydanie niezidentyfikowane, być może Venezia: I. Tacuinus, 21 XI 1502. 2 (Adams D-522).

ad 51. Przypuszczalnie: Guillelmus Peraldus (? - ca 1270), Sermones de tempore et de sanctis. Ed. Henricus Bebel, cum Tabula Vendelini Steinbach, Tübingen: Io. Otmar pro Frid. Meynberger, 18 II 1499. $2^{\circ}$ (GW 12048).

ad 52. Petrus Lombardus (? - ca 1160), Sententiarum textus, Basel: L. Hornken, impensis A. Petri, 28 VII 1513, 2. BJ16 P-503; VD16 P 1872.

Prow. 1. [Stanisław Smoła z Wolborza] na górnym i dolny obcięciu bloku monogram SN z krzyżykiem; 2. A R(everendo) D(omi)no Simone Sacristiano Cathedr(alis) Eccl(essiae) arcen(sis) huic Biblioth(ecae) d(onatus); 3. Augustianie 
Kraków - pieczęć: Biblioteka KK. Augustianów w Krakowie. Przy kościele św. Katarzyny. Obecnie Biblioteka Jagiellońska, sygn. Aug. 10026.

\section{Bibliografia}

Adams H.M., Catalogue of Books Printed on the Continent of Europe 1501-1600 in Cambridge Libraries, t. 1-2, Cambridge: Cambridge University Press 1967.

Antosiewicz K., Katalog inkunabułów Biblioteki Kapituły Metropolitalnej w Krakowie, "Analecta Cracoviensia" 1980, t. 12.

Antykwariat "Rara Avis" 116. aukcja antykwaryczna ksiażki-rękopisy - plakaty, Kraków 20 lutego 2016, Kraków 2016.

Antykwariat "Rara Avis" 121. aukcja antykwaryczna ksiązki-plakaty, Kraków 21 października 2017, Kraków 2017.

Benis A., Materyaty do historyi drukarstwa i ksieggarstwa w Polsce. II. Inwentarze bibliotek prywatnych (1546-1553), „Archiwum do dziejów literatury i oświaty w Polsce" 1892, t. 7, s. 202-240.

Copinger W.A., Supplement to Hain's Repertorium Bibliographicum, cz. 1, London: Henry Sotheran and Co. 1895.

French books III E IV: Books published in France before 1601 in Latin and languages other than French, t. 1-2, red. A. Pettegree, M. Walsby, Leiden-Boston: Brill 2012.

Gesamtkatalog der Wiegendrucke, t. 1-7, Leipzig, Verlag von Karl W. Hiersemann, 1925-1940, t. 8-12: Stuttgart-Berlin: Anton Hiersemann, Akademie Verlag 1978-2013.

Hajdukiewicz L., Biblioteka Macieja z Miechowa, Wrocław: Zakład Narodowy im. Ossolińskich, Wydawnictwo Polskiej Akademii Nauk 1960.

Incunabula quae in bibliothecis Poloniae asservantur, t. 1, moderante A. Kawecka-Gryczowa composuerunt M. Bohonos, E. Szandorowska, Wrocław: Zakład Narodowy im. Ossolińskich - Wydawnictwo 1970.

Incunabula quae in bibliothecis Poloniae asservantur, t. 2: Addenda. Indices, moderante A. Kawecka-Gryczowa composuerunt M. Bohonos, M. Spandowski, E. Szandorowska, Wrocław: Zakład Narodowy Imienia Ossolińskich - Wydawnictwo 1993.

Inkunabuły Biblioteki Jagiellońskiej, oprac. A. Lewicka-Kamińska przy współudziale H. Friedberg, M. Kowalczyk, L. Tabeau, Kraków: Nakładem Uniwersytetu Jagiellońskiego 1962.

Inwentarz rękopisów Biblioteki Jagiellońskiej: nr 4175-6000, oprac. W. Wisłocki, Kraków: Towarzystwo Przyjaciół Biblioteki Jagiellońskiej 1938.

Katalog druków XVI wieku w zbiorach Biblioteki Uniwersyteckiej w Warszawie, t. 6, P-Ska, red. H. Mieczkowska, Warszawa: Wydawnictwo Uniwersytetu Warszawskiego 2016.

Katalog druków XVI wieku ze zbiorów Biblioteki Jagiellońskiej w Krakowie. BJ16, red. M. Malicki, t. 1-7, Baden-Baden: Verlag Valentin Koerner 2002-2005. 
Katalog inkunabutów Biblioteki Naukowej PAU i PAN w Krakowie, oprac. T. Dąbrowa, E. Knapek, J. Wojtowicz, Kraków: Polska Akademia Umiejętności 2015.

Krukowski J., Nauczyciele szkót parafialnych Krakowa w XVI wieku, Kraków: Wydawnictwo Naukowe Akademii Pedagogicznej 2007.

W. Kujawski, Wykaz święconych z najstarszej księgi akt działalności biskupów włocławskich (Kurozwęckiego i Przerębskiego - lata 1496-1511), „Archiwa Biblioteki i Muzea Kościelne" 1999, t. 72.

Lewicka-Kamińska A. przy współudziale H. Friedberg, Inkunabuły Biblioteki Jagiellońskiej. Katalog przybytków za lata 1962-1967, „Biuletyn Biblioteki Jagiellońskiej" 1966, nr 2.

Łosowska A., Marcin (Łysy) z Krakowa, kanonik przemyskiej kapituły katedralnej i jego biblioteka, "Rocznik Przemyski” 2010, z. 3, s. 19-26.

Metryka czyli album Uniwersytetu Krakowskiego z lat 1509-1551, wyd. A. Gąsiorowski, T. Jurek, I. Skierska przy współpracy R. Grzesika, Warszawa: Wydawnictwo Neriton 2010.

Najstarsza księga promocji Wydziału Sztuk Uniwersytetu Krakowskiego z lat 1404-1541, wyd. A. Gąsiorowski, T. Jurek, I. Skierska, Warszawa: Instytut Historii PAN 2011.

Netherlandish books. Books Publisched in the Low Countries and Dutch Books Printed Abroad before 1601, t. 1-2, red. A. Pettegree, M. Walsby, Leiden-Boston: Brill 2011.

Piekarski K., Inwentarz inkunabułów Bibljotek Polskich. Serja Pierwsza, Kraków: Nakł. Krakowskiego Koła Bibljotekarzy 1925.

Spandowski M., Polskie zbiory inkunabułów zniszczone, rozproszone i przemieszczone w czasie $i$ w wyniku II wojny światowej, „Rocznik Biblioteki Narodowej” 2013, t. 44 , s.

Szelińska W., Biblioteki profesorów Uniwersytetu Krakowskiego w XV i początkach XVI wieku, Wrocław: Zakład Narodowy im. Ossolińskich, Wydawnictwo Polskiej Akademii Nauk 1966.

Das Verzeichnis der im deutschen Sprachbereich erschienenen Drucke des 16. Jahrhunderts, t. 1-22, Stuttgart: Anton Hiersemann Verlag 1983-1995, https://www. vd16.de.

Wolff A., Projekt instrukcji wydawniczej dla pisanych źródeł historycznych do połowy XVI wieku, "Studia Źródłoznawcze” 1957, t. 1, s. 151-181. 


\title{
JAKUB ŁUKASZEWSKI
}

\section{Register of books belonging to Stanisław Smoła of Wolborz in an incunabulum held in the collections of Poznań University Library}

\begin{abstract}
In 2017 Poznań University Library purchased an edition of Wilhelm Durant's Rationale divinorum officiorum (Nürnberg: Antonius Koberger, 19 IV 1480, 2º. The front fly-leaf of the incunabulum bears a list, drew up in 1553, of a number books. This article presents the history of this particular volume (heretofore believed to have been lost during the war) and provides an in-depth analysis of the included list. As it can be evidenced from the register, the owner of this particular book collection was Stanisław Smoła of Wolborz (1st. half of the $16^{\text {th }} \mathrm{c}$.), a bachelor of arts and rector of the school attached to St. Szczepan (Stephen) church in Cracow. The article is complemented with an annotated edition of the book register.
\end{abstract}

Keywords: book register, edition, incunabulum, old prints, Stanisław Smoła (Szmola) of Wolborz, Paweł of Piotrków, $16^{\text {th }}$ century Cracow book collections. 
